\title{
Inheritance of plant height, straw yield and flag leaf area in MBB x Gavi- ota durum wheat (Triticum durum Desf.) cross
}

\author{
Manel SALMI ${ }^{1,2}$, Zine El Abidine FELLAHI ${ }^{3}$, Abdelkader BENBELKACEM ${ }^{4}$, Amar BENMAHAMMED ${ }^{5}$, \\ Hamenna BOUZERZOUR ${ }^{5}$
}

Received March 02, 2021; accepted November 02, 2021.

Delo je prispelo 2. marca 2021, sprejeto 2. novembra 2021

\begin{abstract}
Inheritance of plant height, straw yield and flag leaf area in MBB x Gaviota durum wheat (Triticum durum Desf.) cross

Abstract: Plant height, straw mass and flag leaf area are recognized by physiologists as morphological markers of drought stress tolerance. Developing varieties intended for arid and semi-arid zones need to select for these traits. Understanding the genetic control of a given trait helps breeder to handle the segregating populations under study in a more efficient and consistent manner by choosing the best breeding method available to realize significant genetic advance. For this purpose, six generations: parents, $\mathrm{F} 1, \mathrm{~F} 2, \mathrm{BC} 1, \mathrm{BC} 2$, derived from $\mathrm{MBB}$ $\mathrm{x}$ 'Gaviota' durum wheat (Triticum durum Desf.) cross were grown to investigate the nature of gene action involved in the inheritance pattern of the three traits. The results indicated that the six-parameter model fitted the best the data related to the variability present in the generation means of the studied traits. Generation mean analysis indicated that non-allelic interactions were important factors controlling the expression of these characters with complementary type of gene action governing FLA and STW inheritance. High heritability estimates, moderate to high expected responses to selection, significant genetic correlations with grain yield and greater role of non-additive effects in controlling the inheritance of the three studied traits suggested that breeding methods exploiting both fixable and non-fixable components be applied to break unfavorable linkage and to accumulate useful genes in the base population, followed by mono-trait or index based selection in late advanced generations.
\end{abstract}

Key words: gene effects; non-allelic interaction; durum wheat; plant height; straw yield; flag leaf area; heritability
Višina rastlin, masa slame in površina lista zastavičarja so od fiziologov prepoznane morfološke lastnosti, ki nakazujejo toleranco na sušni stres

Izvleček: Višina rastlin, masa slame in površina lista zastavičarja so od fiziologov prepoznane morfološke lastnosti, ki nakazujejo toleranco na sušni stres. Sorte, vzgojene za sušna območja morajo biti izbrane glede na lastnosti, ki omogočajo prenašanje suše. Razumevanje genetske kontrole za določeno lastnost pomaga žlahtniteljem uravnavati različne populacije $\mathrm{v}$ raziskavi na bolj učinkovit in verodostojen način pri izbiri najboljše metode žlahtnenja za dosego pomembne genetske prednosti. $\mathrm{V}$ ta namen je bilo gojeno šest generacij rastlin iz križanja starševske generacije, F1, F2, BC1, BC2 z MBB x 'Gaviota’ trde pšenice (Triticum durum Desf.) kot osnova za preučevanje delovanja genov, ki so vključeni v vzorec dedovanja treh lastnosti. Rezulatati so pokazali, da se je model šestih parametrov najbolje prilegal podatkom, povezanih $\mathrm{z}$ variabilnostjo preučevanih lastnosti kot povprečje v generaciji. Analiza generacijskih povprečij je pokazala, da so bile nealelske interakcije pomemben dejavnik za nadzor izražanja tistih lastnosti, ki so komplementarne delovanju genov in ki vodijo FLA in STW dedovanje. Velike vrednosti dednosti, zmerne glede na pričakovan odziv selekcije, značilna genetska korelacija s pridelkom zrnja in večja vloga neaditivnih učinkov pri kontroli dednosti treh preučevanih lastnosti nakazujejo, da bi žlahtniteljske metode, ki uporabljajo vezane in nevezane komponente lahko bile uporabljene za prekinitev nezaželjenih povezav genov in pospešitev uporabnih genov v osnovnih populacijah, ki bi jim sledil izbor posameznih ali indeksiranih lastnosti v kasnejših izboljšanih generacijah.

Ključne besede: učinki genov; nealelske interakcije; trda pšenica; višina rastlin; pridelek slame; površina lista zastavičarja; dednost

\footnotetext{
1 University of Mostefa Ben Boulaid, Life and Natural Sciences Faculty, Ecology and Environment Department, Batna, Algeria

2 Corresponding author, e-mail: salmi.mnl@gmail.com

3 University of Mohamed El Bachir El Ibrahimi, Natural, Life and Earth Sciences and the Universe Faculty, Agronomy Department, Bordj Bou Arréridj, Algeria

4 Algerian National Institute of Agronomic Research (INRAA), Research Unit of Constantine, Algeria

5 University of Ferhat Abbas, Life and Natural Sciences Faculty, Ecology and Plant Biology Department, Setif, Algeria
} 


\section{INTRODUCTION}

In the arid and semi-arid regions, rainfed grown durum wheat (Triticum durum Desf.) crop suffers from the combined effects of drought and heat stresses, undergoing substantial grain yield losses (Royo et al., 2014; Lui et al., 2015). To minimize yield decline, drought tolerance improvement is then seen as a key breeding component for the development of cultivars devoted to these environments, where reducing wind erosion and meeting livestock feeding requirement have heightened the importance of increasing straw production along with grain yield. In fact, crop residues are usually not burned but either maintained to protect soil from wind erosion or grazed and straw is balled, stored and fed to livestock during the winter months (Annichiarico et al., 2005; Chenaffi et al., 2011). In this context plant height, a straw yield correlated trait, is seen as an important characteristic influencing cultivars adoption under such growing conditions (Rabti et al., 2020; Jatayev et al., 2020; Haddad et al., 2021). Because of their straw yield advantage, tall varieties, derived from land-races, are still cultivated and not replaced by newly released reduced height cultivars (Rabti et al., 2020). For a full expression of their potential, dwarf wheat varieties need to be grown in favorable, well-watered conditions which permit application of relatively high levels of nitrogen fertilizer which is usually not the case in arid and semi-arid environments. This type of plant material becomes, under drought stress conditions, too short, yielding less than tall varieties, showing reduced flag leaf area, kernel size, kernel $\mathrm{Zn}, \mathrm{Fe}$, $\mathrm{Mg}$ and $\mathrm{Mn}$ concentration, coleoptiles, and roots length (Aziz et al., 2017; Velu et al., 2017; Jatayev et al., 2020; Rabti et al., 2020). Positive relationship between plant height and grain yield, under drought stress growing conditions, implied that there is a minimum height below which grain yield limitation becomes evident (Slafer et al., 2005; Royo et al., 2014). in this context, Yani and Rashidi (2012) reported that straw yield and plant height had positive and significant role in the expression of grain yield under drought conditions. Asadi et al. (2019) noted that straw yield explained $65 \%$ of grain yield variation and exerted substantial direct effect on grain yield under water deficit conditions. Belagrouz et al. (2018) reported significant correlation between grain yield water use efficiency, harvest index and plant height, suggesting that selection for plant height and harvest index could improve both water use efficiency and grain yield under drought prone environments. Flag leaf is the main photosynthetic organ providing the major assimilate required for spike growth. It senses environmental signals and consequently adapts to surrounding environment by minimizing area reduction and delaying senescence, caused by termi- nal drought stress (Farook et al., 2009; Belkherchouche et al., 2015). Joshi et al. (1984) found that flag leaf size was positively correlated with grain yield, suggesting that optimal flag leaf dimensions could be an important breeding target under drought prone environments. Information on straw yield, plant height and flag leaf area inheritance can assist developing adapted cultivars for areas practicing cereal-livestock farming systems and conservation agriculture (Chenaffi et al., 2011; Jatayev et al., 2020). Genetic variation for quantitative characters in segregating population is of prime concern to breeders. It determines selection efficiency which depends upon the nature and magnitude of genetic variability available. Genetic models devoted to the estimation of different genetic effects have been developed. Among these models, generation means analysis provides information on the relative importance of gene effects due to additive, dominance deviations and non-allelic interactions, in determining generation means (Mather and Jinks, 1982; Shayan et al., 2018; Salmi et al., 2019). Plant height was found to be controlled mainly by over dominance while flag leaf area was reported to be mostly under additive control combined with partial dominance and epistatic gene actions (Saleem et al., 2005; Shabbir et al., 2012; Yang et al., 2016). Salmi et al. (2019) found that dominance acted in the direction of increased plant height. Joshi and Sharma (1984) reported that genes affecting smaller leaves are partially dominant over genes affecting larger leaves. Evidence for non-allelic interactions was reported and linkage among loci appeared to be an important component of flag leaf dimensions heredity (De Pace et al., 2001). The present study aimed to investigate the inheritance pattern of straw yield, plant height and flag leaf area in a durum wheat cross involving a tall and a semi-dwarf varieties.

\section{MATERIALS AND METHODS}

\subsection{SITE, PLANT MATERIAL, AND EXPERIMEN- TAL DESIGN}

Two durum wheat (Triticum durum Desf.) varieties, namely Gaviota (GTA), a semi-dwarf cultivar derived from 'Crane' /4/ 'Polonicum PI 185309'//Triticum glutinosum enano/2 * 'Tehuacan 60'/3/'Grulla' cross (http:// wgb.cimmyt.org/gringlobal/AccessionDetail.aspx?id= 1783 ), and a tall cultivar, Mohammed Ben Bachir (MBB), a head-row selection derived from a land race adapted to Setif's high plateaus region (Algeria), were hybridized during the 2015-2016 cropping season at the Field Crop Institute, Agricultural Experimental Station of Setif (ITGC, AES, $36^{\circ} 12^{\prime} \mathrm{N} 05^{\circ} 24^{\prime} \mathrm{E}, 1080 \mathrm{~m}$ above sea level, 
Setif, Algeria). During the 2016-2017 cropping season, $\mathrm{F}_{1}$ was selfed to produce $\mathrm{F}_{2}$, and crossed to the parents to obtain back cross generations $\left(\mathrm{BC}_{1}\right.$ and $\left.\mathrm{BC}_{2}\right)$. The parents were crossed again to get the first filial generation $\left(\mathrm{F}_{1}\right)$. The following cropping season (2017-2018), the six basic generations were grown in a randomized completed block design, with five replications. Parents, $\mathrm{F}_{1}$, and BC's generations were sown in one row, $2 \mathrm{~m}$ long, $20 \mathrm{~cm}$ interrow spacing and $10 \mathrm{~cm}$ plant-plant spacing in the row. $\mathrm{F}_{2}$ generation was sown in thirty rows $2 \mathrm{~m}$ long. Recommended cultural practices for the area were followed as reported in Salmi et al. (2019).

\subsection{DATA COLLECTION AND ANALYSIS}

Data were collected from 5, 5, 10, and 30 plants per replication for the parents, $\mathrm{F}_{1}, \mathrm{BC}$ 's, and $\mathrm{F}_{2}$ generations, respectively. Prior to harvest, length of the main stem of each plant was measured from the ground level to the base of the spike and recorded as plant height estimate in $\mathrm{cm}$ (PHT, cm). Straw mass (STM, g plant ${ }^{-1}$ ) was determined as the difference between above ground plant biomass (BIO, g plant ${ }^{-1}$ ) and plant grain yield (GY, g plant ${ }^{-1}$ ). Flag leaf area (FLA, $\mathrm{cm}^{2}$ ) was estimated by the product of leaf length x leaf width x 0.749 (Spagnoletti-Zeuli and Qualset, 1990). Collected data were subjected to an analysis of variance using Cropstat software (2007) to test generation effect. Whenever this effect, tested against the residual mean square, was significant, genetic analysis for the specific trait was undertaken. To test the presence of additive vs. dominance genes effects, contrast method (Steel and Torrie, 1982) was applied to check the significance of the following comparisons: $\mathrm{F}_{1}$ vs. mid-parent, $\mathrm{P}_{1}$ vs. $\mathrm{P}_{2}, \mathrm{~F}_{2}$ vs. average $\mathrm{BC}$ 's, and $\mathrm{BC}_{1}$ vs. $\mathrm{BC}_{2}$. The notations adopted for gene effects were [m], [d], [h], [i], [j], and [1] representing main, additive and dominance gene effects, and additive $\times$ additive, additive $\times$ dominance, and dominance $\times$ dominance epistatic interactions, respectively. The appropriate genetic model (three vs. six parameters) was also determined using both ABCD and joint scaling tests. These tests provide information regarding the absence or the presence of gene interactions (Mather and Jinks, 1982). Significance of any one or both scaling tests implies inadequacy of the additive-dominance model. The C and D scaling tests provide check for dominance $\mathrm{x}$ dominance (l) and additive $\mathrm{x}$ additive (i) types of epistasis, respectively. The genetic parameters [m], [d], [h], [i], [j], and [1] were estimated by weighted least square method. The purpose of using weights was to account for differential precision with which means of different generations were estimated based on varying sample size. Gene effects were tested for significance using the t-test (Kearsey and Pooni, 1996). Three vs six-parameter models testing ware performed using GENMEANS subroutine implemented in Tnaustat software (Manivannan, 2014). Genotypic and environmental variance components, of the measured traits, were estimated by equating the observed values of the different generations, according to Mather and Jinks, (1982) as follows: $\sigma_{\mathrm{E}}^{2}=1 / 4\left(\sigma_{\mathrm{P1}}^{2}\right.$ $\left.+\sigma_{\mathrm{P} 2}^{2}+2 \sigma_{\mathrm{F} 1}^{2}\right), \sigma_{\mathrm{D}}^{2}=\left(2 \sigma_{\mathrm{F} 2}^{2}-\sigma_{\mathrm{BC} 1}^{2}-\sigma_{\mathrm{BC} 2}^{2}\right)$ and $\sigma_{\mathrm{H}}^{2}=4$ $\left(\sigma_{\mathrm{F} 2}^{2}-1 / 2 \sigma_{\mathrm{D}}^{2}-\sigma_{\mathrm{E}}^{2}\right)$. The significance of the mean value of a particular parameter was tested against its corresponding standard error, via a Student's t-test, as suggested by Mather and Jinks (1982). Broad-sense heritability ( $\left.\mathrm{H}^{2} \mathrm{bs}\right)$ was calculated according to Kearsey and Pooni, (1996), as follow: $\mathrm{H}^{2} \mathrm{bs}=\left(\sigma_{\mathrm{D}}^{2}+\sigma_{\mathrm{H}}^{2}\right) /\left(\sigma_{\mathrm{D}}^{2}+\sigma_{\mathrm{H}}^{2}+\sigma_{\mathrm{E}}^{2}\right)=\left(\sigma_{\mathrm{G}}^{2}\right) /$ $\left(\sigma_{P}^{2}\right)$, where $\sigma_{D}^{2}, \sigma_{H}^{2}, \sigma_{E}^{2}, \sigma_{G}^{2}$, and $\sigma_{P}^{2}$ stand for the additive, dominance, environmental variance components, genetic, and phenotypic variances, respectively. Narrow sense heritability ( $\mathrm{h}^{2} \mathrm{~ns}$ ) was estimated according to $\mathrm{Hal}-$ lauer and Miranda Filho (1989) as follow: $h^{2}{ }_{n s}=\sigma_{D}^{2} /\left(\sigma_{D}^{2}\right.$ $\left.+\sigma_{\mathrm{H}}^{2}+\sigma_{\mathrm{E}}^{2}\right)=\left(\sigma_{\mathrm{D}}^{2}\right) /\left(\sigma_{\mathrm{P}}^{2}\right)$, Standard errors (SE) of these estimates were calculated as: $\mathrm{SE}{ }_{(\mathrm{h} 2 \mathrm{bs})}=\left[\mathrm{SE}\left(\sigma_{\mathrm{G}}^{2}\right)\right] /\left(\sigma_{\mathrm{P}}^{2}\right)$ and $S E_{(h 2 n s)}=\left[\operatorname{SE}\left(\sigma_{D}^{2}\right)\right] /\left(\sigma_{P}^{2}\right)$. Significance of these parameters, $\mathrm{h}_{\text {bs }}{ }_{\text {and }}$ and $\mathrm{h}^{2}{ }_{\mathrm{ns}}$ was tested using a t-test equals to the ratio of heritability over its standard error (Halloran et al., 1979). The expected response to selection (ERS) was derived according to Sing and Chaudhary (1999) as follows: ERS $=2.06{ }^{*} \mathrm{~h}^{2}{ }_{\text {bs }}{ }^{*} \sqrt{\sigma^{2} \text {, }}$ and expressed as percent of the over mean $\left(\mathrm{X}_{\mathrm{bar}}\right)$ of the given trait: ERS (\%) $=(100 *$ ERS $) / \mathrm{X}_{\mathrm{bar}}$. Relationship between studied traits and grain yield was inspected through genotypic correlation coefficient ( $\mathrm{rg}$ ), which was derived as the ratio of covariance to the square root of the product of the corresponding variance of the two traits considered. Genotypic covariance was determined using the property of the analysis of variance of the sum of two variables as suggested by Kwon and Torrie (1964) and described in Mansouri et al. (2018), using Past software (Hammer et al., 2001). The standard error of rg was derived using the formulae of Reeves (1955), reported by Koots and Gibson (1996), as follows: $\mathrm{SE}_{\mathrm{rg}}=\left[\left(1-\mathrm{rg}^{2}\right) / \sqrt{ } 2\right] *\left[\left(\sqrt{S E}_{\mathrm{h}^{2} \mathrm{i}} * \mathrm{SE}_{\mathrm{h}^{2} \mathrm{j}}\right) /\right.$ $\left.\left(\sqrt{ } h^{2} i^{\star} \sqrt{ } h^{2} j\right)\right]$, where $h^{2} i$ and $h^{2} j$ are the traits heritability's. Student's t-test was used to determinate the significance of the correlation coefficient.

\section{RESULTS AND DISCUSSION}

\subsection{VARIATION AND MEAN PERFORMANCES}

Significant generation effect was revealed for flag leaf area (FLA), plant height (PHT) and straw mass (STM) by the analysis of variance, indicating the presence of substantial genetic variability and allowing to 
carry out in deep bio-metrical analysis (Table 1). A significant generation effect is a prerequisite to perform the inheritance study of the targeted traits applying generation means analysis model. Among generations traits mean estimates, varied from 19.67 to $29.70 \mathrm{~cm}^{2}$ for FLA, from 82.00 to $136.25 \mathrm{~cm}$ for PHT, and from 12.32 to 31.98 g plant $^{-1}$ for STM (Figures 1, 2 and 3). Contrast analysis indicated that deviations between parental mean values for the studied traits were significant (Table 1). 'Gaviota' had significantly greater FLA $\left(29.70 \mathrm{~cm}^{2}\right)$ than MBB $\left(26.08 \mathrm{~cm}^{2}\right)$, while MBB showed significantly greater PHT $(136.25 \mathrm{~cm})$ and STM (31.55 $\left.\mathrm{g} \mathrm{plant}^{-1}\right)$ than 'Gaviota' whose mean values for both traits were $86.87 \mathrm{~cm}$ and $15.24 \mathrm{~g} /$ plant, respectively (Figure 1, 2 and 3).
These results suggested that the crossed parents carry different allelic combinations involved in the genetic control of the studied traits. On average, F1 exhibited equal FLA $\left(29.35 \mathrm{~cm}^{2}\right)$ to the best parent GTA $\left(29.70 \mathrm{~cm}^{2}\right)$, equal PHT $(82.00 \mathrm{~cm})$ to the semi-dwarf parent GTA $(86.87 \mathrm{~cm})$ and equal STM (31.98 g plant $\left.^{-1}\right)$ to the tall parent $\mathrm{MBB}$ (31.55 $\left.\mathrm{g} \mathrm{plant}^{-1}\right)$, within the limits of their standard errors (Figures 1, 2 and 3). Furthermore, F1 means differed significantly from mid-parent average for PHT and STM but not for FLA, suggesting that dominance was predominantly involved in the genetic control of PHT and STM; while additive genetic control was predominantly expressed for FLA (Table 1, Figures 1, 2 and 3). Dominance acted in the direction of

Table 1: Mean square deviations of the analysis of variance for flag leaf area, plant height and straw mass in Gaviota $\mathrm{x}$ MBB durum wheat cross

\begin{tabular}{lllll}
\hline Sources of variation & DF & FLA $\left(\mathrm{cm}^{2}\right)$ & PHT $(\mathrm{cm})$ & STM $(\mathrm{g} / \mathrm{plant})$ \\
\hline Generations & 5 & $89.56^{* *}$ & $2091.65^{* *}$ & $398.08^{* *}$ \\
Replications & 4 & 9.56 & 8.81 & 25.00 \\
Homogeneous (Homo) & 2 & $21.56^{* *}$ & $4504.12^{* *}$ & $455.19^{* *}$ \\
P1 vs P2 & 1 & $8.10^{* *}$ & $1190.50^{* *}$ & $18.10^{* *}$ \\
F1 vs 1/2(P1+P2) & 1 & $2.55^{\text {ns }}$ & $568.92^{* *}$ & $6.69^{*}$ \\
Heterogeneous (Het) & 2 & $20.38^{\text {ns }}$ & $579.97^{* *}$ & $164.99^{\text {ns }}$ \\
F2 vs 1/2(BC1+BC2) & 1 & $4.95^{*}$ & $177.96^{* *}$ & $8.88^{* *}$ \\
BC1 vs BC2 & 1 & $16.57^{* *}$ & $9.17^{* *}$ & $1.11^{\text {ns }}$ \\
Homo vs Het & 1 & $89.86^{* *}$ & $56.58^{* *}$ & $20.43^{* *}$ \\
Residual & 20 & 4.05 & 5.12 & 36.72 \\
\hline
\end{tabular}

Ns, ${ }^{* * *}$ : non-significant and significant effects at $5 \%$ and $1 \%$ probability level, respectively. FLA: Flag leaf area, PHT: Plant height; STM : Straw mass

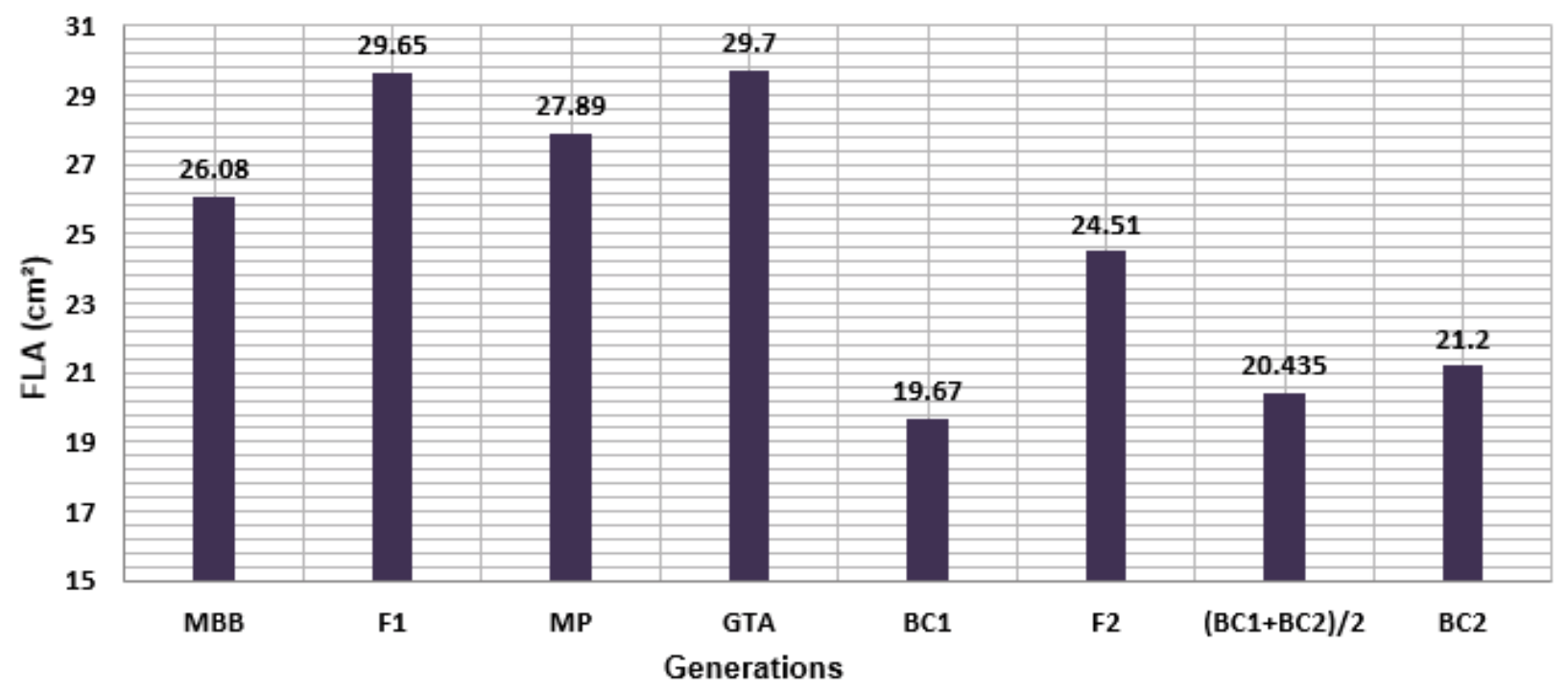

Figure 1: Mean of flag leaf area of the basic generations 
reduced PHT and increased STM, suggesting that GTA carries more dominant genes controlling PHT, while MBB carries more dominant genes controlling STM. Based F1 data analysis, these results agreed with findings of several authors who reported that non-additive genetic effects appeared as an important component of the genetic architecture of PHT and STM, while additive gene effects were prevalent for FLA (Saleem et al., 2005; Shabbir et al., 2012; Yang et al., 2016). Mean values of the F2 generation deviated significantly from the average of BCs generations for the three studied traits, being significantly higher and laying within the parental range for
PHT and STM and outside of this range for FLA (Table 1, Figures 1,2 and 3).

\subsection{GENE EFFECTS}

$\mathrm{ABCD}$ and joint scaling tests, applied to appraise presence of epistasis, were found significant, invaliding the additive-dominance model adequacy for explaining the inheritance pattern of PHT, STM and FLA, and suggesting the adoption of higher than three-parameter model (Table 2). These results indicate that higher order

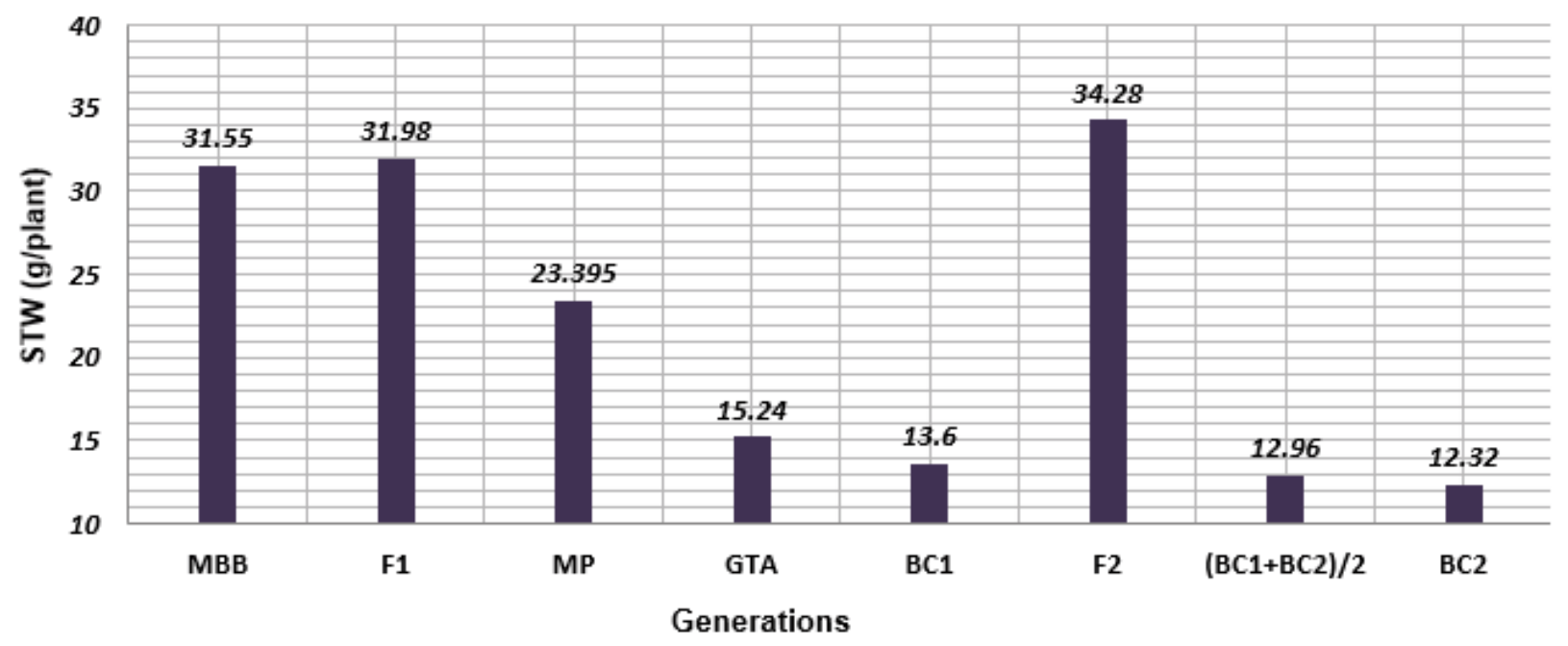

Figure 2: Mean of straw yield of basic generations

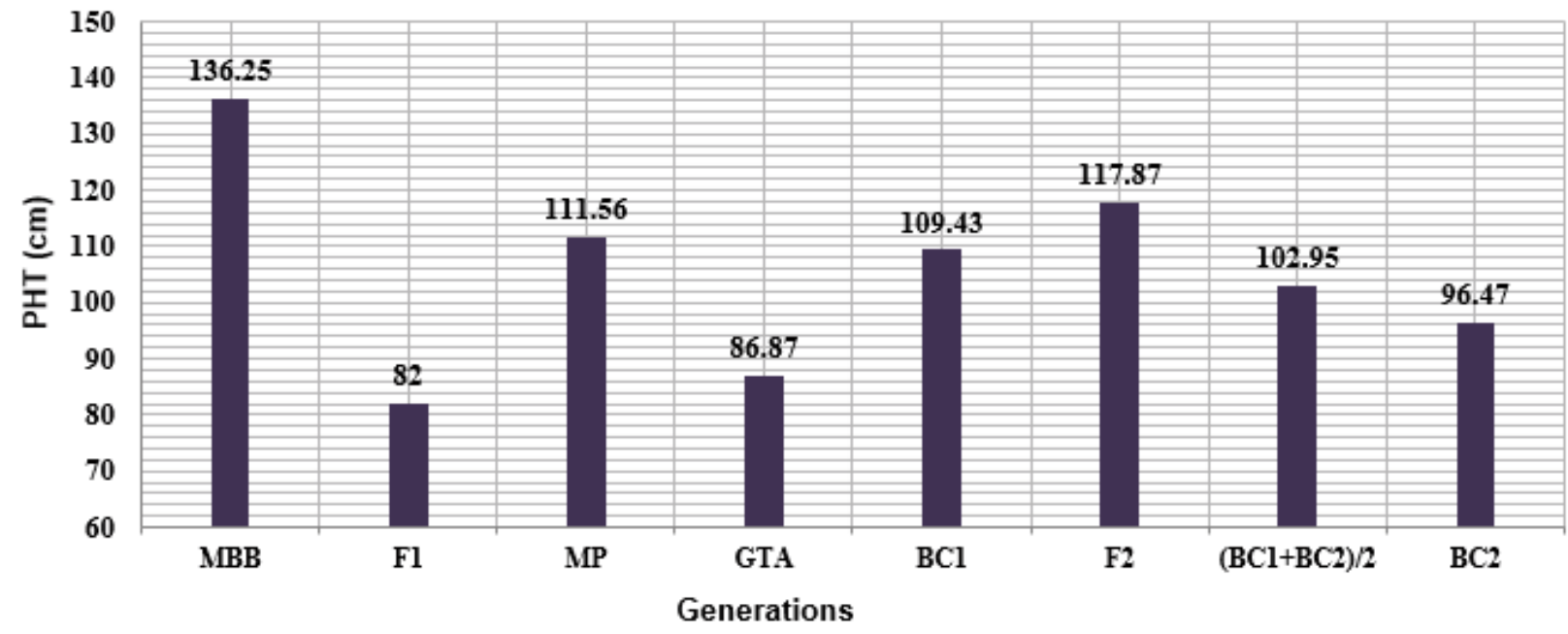

Figure 3: Mean of plant height of the basic generations 
inter-allelic interactions played an important role in the expression of the measured traits, and additive-dominance model alone will not be sufficient to deal with the inheritance pattern of such traits. Estimates of the gene effects derived from this six-parameter model are given in Table 2. Gene main effect [m] was significant for all three analyzed traits, indicating that these traits are controlled by minor genes and quantitatively inherited. For PHT, additive $[\mathrm{d}]$ and dominance $[\mathrm{h}]$ gene affects, and additive ${ }^{*}$ additive [i] and additive ${ }^{\star}$ dominance $[\mathrm{j}]$ nonallelic interactions were significantly involved in the inheritance of this trait. Dominance [h] gene effects and additive ${ }^{\star}$ additive [i] non-allelic interactions came out as the salient features of the genetic control of this character as this is indicated by the high absolute values of the genetic parameters. The negative sign of the additive * dominance $[\mathrm{j}$ ] component indicated that genes involved in the control of this trait were dispersed the parents.

These results agreed with Novoselović et al. (2004), Ojaghi and Akhundova (2010), Mohamed et al. (2013), Dorri et al. (2014) and Fellahi et al. (2016) who reported that non-additive gene effects played an important role in the inheritance of PHT. Salmi et al. (2019) found that dominance acted in the direction of in- creased plant height But Akhtar and Chowdhry (2006) as well as Hannachi et al. (2013) reported that additive gene effects were predominant in the genetic control of this character. For STM, the additive [d] gene effects were not significant while dominance [h] gene effects, additive ${ }^{\star}$ additive $[\mathrm{i}]$, additive ${ }^{\star}$ dominance $[\mathrm{j}]$ and dominance ${ }^{\star}$ dominance [1] allelic interactions were significant. The gene effects $[\mathrm{h}]$, additive ${ }^{\star}$ additive [i], and dominance ${ }^{\star}$ dominance [1] allelic interactions exhibited the largest effects. Being significant and of the same sign, dominance $[\mathrm{h}]$ gene effects and dominance ${ }^{*}$ dominance [1] non-allelic interactions suggested the implication of complementary type of epistasis in the genetic control of this trait. A greater magnitude of dominance [h] compared to additive [d] gene effects, as this is the case in the present study, for this trait, arises, according to Kearsey and Pooni (1996), when genes are dispersed in the parents. For FLA, the additive ${ }^{\star}$ dominance $[\mathrm{j}]$ epistatic component was not significant while the additive [d] and dominance $[\mathrm{h}]$ gene effects, the additive ${ }^{*}$ additive [i], and dominance ${ }^{\star}$ dominance [1] allelic interactions were significant. The dominance ${ }^{*}$ dominance [1] component exhibited the largest effect. The implication of complementary type of epistasis in the genetic control

Table 2: Scaling tests, gene action types, heritability $\left(\mathrm{H}^{2} \mathrm{bs}, \mathrm{h}^{2} \mathrm{~ns}\right)$, expected response to selection (ERS) and genotypic correlation $\left(\mathrm{rg}_{\mathrm{GY}} / \ldots\right)$ estimates for plant height, straw yield and flag leaf area in MBB x GTA durum wheat cross

\begin{tabular}{|c|c|c|c|c|}
\hline Traits & & PHT & STM & FLA \\
\hline \multirow[t]{4}{*}{ Scaling test } & $\mathrm{A}$ & $9.65 \pm 4.96^{\mathrm{ns}}$ & $37.14 \pm 1.11^{* *}$ & $17.72 \pm 1.71^{* *}$ \\
\hline & B & $31.25 \pm 2.56^{* *}$ & $20.44 \pm 2.18^{* *}$ & $15.86 \pm 0.66^{* *}$ \\
\hline & $\mathrm{C}$ & $84.03 \pm 4.41^{* *}$ & $26.38 \pm 2.65^{* *}$ & $17.04 \pm 1.35^{* *}$ \\
\hline & $\mathrm{D}$ & $21.55 \pm 3.54^{* *}$ & $41.99 \pm 1.69^{* *}$ & $8.12 \pm 1.11^{* *}$ \\
\hline Joint scaling test & $\mathrm{X}^{2}$ & $860.27^{* *}$ & $569.90^{* *}$ & $745.72^{* *}$ \\
\hline \multirow[t]{6}{*}{ Genetic parameters } & $\mathrm{m}$ & $117.79 \pm 1.09^{* *}$ & $34.25 \pm 0.62^{* *}$ & $24.51 \pm 0.32^{* *}$ \\
\hline & [d] & $13.87 \pm 2.78^{* *}$ & $0.19 \pm 1.14^{\mathrm{ns}}$ & $2.89 \pm 0.90^{* *}$ \\
\hline & {$[\mathrm{h}]$} & $-72.67 \pm 7.09^{* *}$ & $75.39 \pm 3.42^{* *}$ & $14.49 \pm 2.23^{* *}$ \\
\hline & [i] & $-43.11 \pm 7.09^{* *}$ & $83.98 \pm 3.39^{* *}$ & $16.24 \pm 2.22^{* *}$ \\
\hline & {$[\mathrm{j}]$} & $-10.84 \pm 2.79^{*}$ & $8.35 \pm 1.21^{* *}$ & $1.08 \pm 0.91^{\mathrm{ns}}$ \\
\hline & {$[1]$} & $2.18 \pm 11.99^{\mathrm{ns}}$ & $141 \pm 5.27^{* *}$ & $49.54 \pm 3.85^{* *}$ \\
\hline Type of gene actions & & ----- & Complementary & Complementary \\
\hline $\mathrm{H}_{\mathrm{bs}}^{2} \pm \mathrm{SE}$ & & $0,98 \pm 0.40^{*}$ & $0,99 \pm 0.41^{\star}$ & $0,98 \pm 0.40^{*}$ \\
\hline $\mathrm{h}_{\mathrm{ns}}^{2} \pm \mathrm{SE}$ & & $0,57 \pm 0.23^{\star}$ & $0.76 \pm 0.31^{\star}$ & $0,39 \pm 0.16^{*}$ \\
\hline $\mathrm{rg}_{\mathrm{GY} /}$ & & $-0.57 \pm 0.15^{\star}$ & $1.21 \pm 0.17^{\star}$ & $0.91 \pm 0.07^{\star}$ \\
\hline ERS & & 8.25 & 22.72 & 7.03 \\
\hline ERS\% & & 6.99 & 99.44 & 29.69 \\
\hline
\end{tabular}

PHT $=$ Plant height, $\mathrm{STM}=$ straw mass, FLA = Flag leaf area. $\mathrm{m}=$ mean main effect, $[\mathrm{d}]=$ assistive effect, $[\mathrm{h}]=$ dominance effect, $[\mathrm{i}]=$ additive $\mathrm{x}$ additive effect, $[\mathrm{j}]=$ additive $\mathrm{x}$ dominance effect, $[1]=$ dominance $\mathrm{x}$ dominance effect. Ns, ${ }^{*}$ and ${ }^{*}=$ non-significant and significant effects at $5 \%$ and $1 \%$ probability levels, respectively 
of this trait is suggested by the dominance gene effects $[\mathrm{h}]$ and the dominance ${ }^{*}$ dominance [l] allelic interaction which were significant and of the same sign. Dominance [h] component was greater than additive [d] gene effects suggesting that genes controlling FLA are dispersed in the parents. In this context Saleem et al. (2005); Inamullah et al. (2006); Munir et al. (2007); Ijaz et al. (2013) and Yang et al. (2016) found that FLA was mostly under additive genetic control combined to partial dominance and epistasis type of gene actions. Joshi and Sharma (1984) mentioned that dominance acted in the direction of reduced FLA.

Shayan et al. (2019) reported that the additive-dominance model fitted best the variation present among generation means for FLA, while for PHT and STM, the six-parameter model was adequate implying the presence of non-allelic interactions in the inheritance of these two traits. Divergence in the result among various studies seems to indicate that genetic model adequacy as well as the preponderance of significant gene effects and non-allelic interactions are dependent upon the cross combination genetic background and the experimental growth conditions experienced. The complementary epistasis type implicated in the inheritance of STM and FLA suggested the possibility of heterosis expression for these two traits. In fact, Punia et al. (2011), referring to Jinks and Jones (1958), mentioned that heterosis is likely to be expressed with greater magnitude in crosses where complementary type of interaction is expressed. The fact that generation means variation fitted a digenic epistatic model suggested that improvement of PHT, STM and FLA would be fairly difficulty compared to the situation where the additive-dominance model was the most adequate. Furthermore, Sirohi and Gupta (1993) suggested that traits showing high magnitude of dominance [h] than additive [d] gene effects, as this is the case for PHT, STM and FLA, in the present study, can be improved through conventional breeding approaches. But selection need to be delayed until later generations when the dominance effects would have diminished and desirable segregants become available.

\subsection{HERITABILITY, EXPECTED RESPONSE TO SE- LECTION, AND GENOTYPIC CORRELATIONS}

Being significant, broad sense heritability estimates for FLA, PHT and STM were appreciably high, taking values of $98.00,98.00$ and $99.00 \%$, respectively. Their corresponding narrow sense counterparts were also significant, but of lower magnitude, being still high for STM (76.00\%), moderate for PHT (57.00\%) and low for FLA $(39.00 \%)$. High $\mathrm{h}^{2} \mathrm{~ns}$ values indicate that the environment influences less the expression of the given character. In fact, estimates of heritability are useful for a breeder to weigh the proportion of variation which is inheritable from that which is non-inheritable. Heritability values observed in the present study were in the range of those reported in similar studies. Fellahi et al. (2020) reported $\mathrm{h}^{2}$ bs values of $86.50 \%$ for PHT and $77.40 \%$ for FLA. Novoselovic et al. (2004) reported $h^{2}$ bs values ranging from 0.54 to 0.81 for PHT of several crosses. These high $\mathrm{H}^{2}$ bs values suggested that these traits are less impacted by environmental variation, and then are easily amenable to improvement. In this context, Johnson et al. (1966) mentioned that since plant height and straw mass heritability were sufficiently high then selection in the $\mathrm{F}_{2}$ for these traits could be effective. So, based on the heritability estimates observed in the present study, STM, FLA and PHT appeared amenable to significant improvement applying early selection.

Genotypic correlation coefficients, relating grain yield (GY) to FLA, PHT and STM, found in this study, were significant, taking values of $0.91,-0.57$ and 1.21 , respectively (Table 2). while PHT was posirivelly correlated with STM $\left(\mathrm{r}=0.315^{* *}\right)$, but negatively correlated with FLA $\left(r=-0.153^{*}\right)$, and STM was positivelly correlated with FLA $\left(r=0.269^{* *}\right)$. These correlation coefficients indicated that selection of high values for FLA and STM will be accompanied by increased GY, but selection to increase PHT had a negative impact on GY and on FLA. The negative correlation relating PHT to GY, observed in the present study, contradicted Ataei et al. (2017) results which showed that GY was positively and highly correlated with PHT and peduncle under drought stress conditions, emphasizing the importance of PHT as selection criterion to improve drought tolerance. In this context and according to Davidson et al. (1992) and Belkherchouche et al. (2015) wheat peduncle is a transient source of water-soluble carbohydrates, playing a crucial role in minimizing grain yield decline under drought stress conditions. Similarly, Mohsin et al. (2009) found that grain yield correlated positively with FLA, PHT, biomass (BIO), under drought stress. Under rainfed growing conditions, Mansouri et al. (2018) reported that above ground plant biomass exhibited significant and positive correlation coefficients with GY, STM and PHT. The expected response to selection estimates were low, being less than $10 \%$ for PHT $\left(8.24 \mathrm{~cm}\right.$ or $6.99 \%, \mathrm{X}_{\text {barF2 }}=117.87$ $\mathrm{cm})$ and high, above $20 \%$, for STM (22.74 $\mathrm{g} \mathrm{plant}^{-1}$ or $\left.99.4 \% \mathrm{X}_{\text {barF2 }}=22.85 \mathrm{~g} \mathrm{plant}^{-1}\right)$, FLA $\left(7.03 \mathrm{~cm}^{2}\right.$ or $26.6 \%$, $\mathrm{X}_{\text {barF2 }}=23.67 \mathrm{~cm}^{2}$ ) (Table 2). These results indicated that, based on the magnitude of the variability expressed by each trait, moderate to appreciable genetic gain could be made via mono trait selection.

Durum wheat production is often impacted by 
drought stress, particularly in the arid and semi-arid regions. To overcome this situation, it is necessary to develop improved varieties devoted to these specific environments. Morphological characters like plant height, flag leaf area, and straw yield, had been identified and proposed as morphological markers for drought tolerance. Breeding procedure for drought tolerance depends upon the pattern of inheritance and the nature of actions of the genes involved in the genetic control of the drought related traits. A better understanding of the complexities of the genetic control of these traits will be useful for cultivar improvement. Globally, from the results of this study, it can be summarized that the additive-dominance model was inadequate, suggesting the adoption of a sixparameter genetic model. Additive [d] and dominance [h] gene effects, and non-allelic interactions ([i], [j] and [1]) were involved in the inheritance of PHT, with the predominance of [h] and [i] components. Complementary type of epistasis was implicated in the inheritance of STM and FLA. These results were in lines with findings of some studies (Novoselovic et al., 2004; Ojaghi and Akhundova, 2010; Mohamed et al., 2013; Dorri et al., 2014; Fellahi et al., 2016) and diverged from those of others studies (Inamullah et al., 2006, Munir et al., 2007; Ijaz et al., 2013; Yang et al., 2016; Shayan et al., 2019), suggesting that genetic model adequacy as well as the preponderance of significant gene effects and non-allelic interactions, governing the inheritance of a given trait, are dependent upon the cross combination genetic background and the experimental growth conditions experienced. Due to the presence of non-allelic interactions PHT, STM and FLA improvement would be fairly difficulty, requiring the implementation of conventional breeding approaches such as the inclusion of F2's showing high performances in multiple crosses for further improvement of the studied traits in order to synthesize a dynamic population accumulating most of the favorable genes. This mating procedure seems to be a good technique to disrupt linkage, to generate usefull recombination and to accumulate favorable genes in the base population. Selection need to be delayed until later generations when the dominance effects would have diminished and desirable segregants become available. This strategy is supported by the high heritability estimates, the moderate to high expected genetic gains and the significant genotypic correlation coeffcicients relating the studied traits to grain yield.

\section{CONCLUSION}

The results of the present study indicated that nonallelic interactions, in addition to additive and dominant gene effects are important factors controlling the expres- sion of PHT, STM and FLA. Application of conventional selection procedure may not be rewarding for the improvement of these characters. But inter mating among the selected segregants followed by few generations of selfing could be useful to break the undesirable linkage and allow accumulation of favorable alleles for improvement of these traits.

\section{REFERENCES}

Akhtar, N., \& Chowdhry, M. A. (2006). Genetic analysis of yield and some other quantitative traits in bread wheat. International Journal of Agriculture and Biology, 4, 523-527.

Annicchiarico, P., Abdellaoui, Z., Kelkouli, M., Zerargui. H. (2005). Grain yield, straw yield and economic value of tall and semi-dwarf durum wheat cultivars in Algeria. Journal of Agricultural Science, 143, 57-64. https://doi.org/10.1017/ S0021859605004855

Asadi, A., Valizadeh, M., Mohammadi, S. A., Khodarahmi. M. (2015). Genetic analysis of some physiological traits in wheat by generation means analysis under normal and water defict conditions. Biological forum, 7, 722-733.

Ataei R., Gholamhoseini, M., Kamalizadeh, M. (2017). Genetic analysis for quantitative traits in bread wheat exposed to irrigated and drought stress conditions. Phyton, 86, 228-235. https://doi.org/10.32604/phyton.2017.86.228

Aziz, T., Mahmood, Z., Mahmood, K., Shazadi, A., Kazi, M., Rasheed, A. (2018). Genotypic variation and genotype $\mathrm{x}$ environment interaction for yield-related traits in synthetic hexaploid wheats under a range of optimal and heatstressed environments. Crop Science, 58, 295-303. https:// doi.org/10.2135/cropsci2017.01.0035

Belagrouz A., Chennafi, H., Bouzerzour, H., Hakimi, M., Razem, R., Hadj Sahraoui, A. (2018). Relationships among water use efficiency and the physio-agronomic traits in durum wheat (Triticum durum Desf.) cultivars assessed under rainfed conditions of the eastern high plateaus of Algeria. The Journal Agriculture and Forestry, 64(3), 159-172. https://doi.org/10.17707/AgricultForest.64.3.14

Belkherchouche, H., Benbelkacem, A., Bouzerzour, H., Benmahammed. A. (2015). Flag leaf and awns ablation and spike shading effects on spike yield and kernel weight of durum wheat (Triticum turgidum L. var. durum) under rainfed conditions. Advances in Environmental Biology, 9(8), 184191.

Chennafi, H., Hannachi, A., Touahria, O., Fellahi, Z.E.A., Makhlouf, M., Bouzerzour, H. (2011). Tillage and residue management effect on durum wheat [Triticum turgidum (L.) Thell. ssp. turgidum conv. durum (Desf.) Mackey] growth and yield under semi-arid climate. Advances in Environmental Biology, 3231-3241.

Cropstat. (2007). CropStat for Windows 7.2. Dapo, Manila IRRI - International Rice Research Institute.

Davidson, D. J. and Chevalier, P. M. (1992). Storage and remobilization of water-soluble carbohydrates in stems of spring wheat. Crop Science, 32, 186-190. https://doi.org/10.2135/cr opsci1992.0011183X003200010038x 
De Pace, C., Snidaro, D., Ciaffi, M., Vittori, D., Ciofo, A., Cenci, A. (2001). Introgression of Dasypyrum villosum chromatin into common wheat improves grain protein quality. Euphytica, 117, 67-75. https://doi.org/10.1023/A:1004095705460

Dorri, P., Khorasani, S. K., Shahrokhi, M. (2014). Generation means analysis. A case study of variance components in KSC 500 generations of maize (Zea mays L.). International Research Journal of Applied and Basic Sciences, 8(2), 194200.

Farooq, M., Wahid, A., Kobayashi, N., Fujita, D., Basra, S. M. A. (2009). Plant drought stress: effects, mechanisms and management. Agronomy for sustainable development, Springer Verlag/EDP Sciences/INRA, 29, 85-212. https://doi. org/10.1007/978-90-481-2666-8_12

Fellahi, Z. E. A., Hannachi, A., Bouzerzour. H. (2020). Expected genetic gains from mono trait and index-based selection in advanced bread wheat (Triticum aestivum L.) populations. Revista Facultad Nacional de Agronomía Medellín, 73, 91319141. https://doi.org/10.15446/rfnam.v73n2.77806

Fellahi, Z. E. A., Hannachi, A., Bouzerzour, H., Dreisigacker, S., Yahyaoui, A., Sehgal, D. (2017). Genetic analysis of morpho-physiological traits and yield components in F2 partial diallel crosses of bread wheat (Triticum aestivum L.). Revista Facultad Nacional de Agronomía Medellín, 70, 8237-8250. https://doi.org/10.15446/rfna.v70n3.61927

Haddad, L., Bachir, A., Yakhlef, N., Benmahammed, A., Bouzerzour, H. (2021). Durum wheat [Triticum turgidum (L.) Thell ssp turgidum conv. durum (Desf.) Mackey] during the past 70-year in Algeria: Performance assessment of a set of historical varieties under rainfed conditions of the eastern high plateaus. Jordan Journal of Biological Sciences, 14. (in press).

Hallauer, A. R., \& Mirinda Filho, J. B. (1989). Quantitative genetics in maize breeding. Second edition, Ames, IOWA State University Press. 468 p.

Halloran, G. M., Knight, R., McWhirter, K. S., Sparrow, D. H. B. (1979). Plant breeding. Knight, R. (Ed.). Poly-Graphics Pty. Ltd. Brisbane, Australia. pp. 61 - 62.

Hammer, O., Harper, D. A. T., Ryan, P. D. (2001). Paleontological statistics software package for education and data analysis. Palaeontologia Electronica, 4(9).

Hannachi, A., Fellahi, Z. E. A. Bouzerzour, H., Boutakrabt. A. (2013). Diallel-cross analysis of grain yield and stress tolerance-related traits under semi-arid conditions in Durum wheat (Triticum durum Desf.). Electronic Journal of Plant Breeding, 4, 1027-1033. https://doi. org/10.1155/2013/201851

Ijaz U., Miullah, S., Kashif. M. (2013). Generation means analysis for five physiological traits of bread wheat under rainfed condition. Universal Journal of Plant Science, 1, 21-26. https://doi.org/10.13189/ujps.2013.010103

Inamullah, A., Hussain, M., Hassan, G. F., Gul, R. (2006). Diallel analysis of the inheritance pattern of agronomic traits of bread wheat. Pakistan Journal of Boutany, 38, 1169-1175.

Jatayev, S., Sukhikh, I., Vavilova, V., Smolenskaya, S. E., Goncharov, N. P., Kurishbayev, A., Zotova L. (2020). Green revolution 'stumbles' in a dry environment: Dwarf wheat with Rht genes fails to produce higher grain yield than tall- er plants under drought. Plant, Cell and Environment, 43, 2355-2364. https://doi.org/10.1111/pce.13819

Johnson, V. A., Biever, K. J., Haunold, A., Schmidt, J. W. (1966). Inheritance of plant height, yield of grain, and other plant and seed characteristics in a cross of hard red winter wheat, Triticum aestivum L.. Crop Science, 6, 307-312. https://doi. org/10.2135/cropsci1966.0011183X000600040011x

Joshi, S. K., Sharma, S. N., Singhania, D. L., Sain. R. S. (2004). Combining ability in the F1 and F2 generations of diallel cross in hexaploid wheat (Triticum aestivum L. em. Thell). Hereditas, 141, 115-121. https://doi.org/10.1111/j.16015223.2004.01730.x

Kearsey, M. J. and Pooni, H. S. (1996). The genetic analysis of quantitative traits. Chapman and Hall, London. 396 p. https://doi.org/10.1007/978-1-4899-4441-2

Koots, K. R., Gibson. J. P. (1996). Realized sampling variances of estimates of genetic parameters and the difference between genetic and phenotypic correlations. Genetics, 143, 1409-1416. https://doi.org/10.1093/genetics/143.3.1409

Kwon, S. H. and Torrie, J. H. (1964). Heritability and inter-relationship among traits of two soybean populations. Crop Science, 4, 196-198. https://doi.org/10.2135/cropsci1964.00 11183X000400020023x

Liu, H., Searle, I. R., Mather, D. E., Able, A. J., Able. J. A. (2015). Morphological, physiological and yield responses of durum wheat to pre-anthesis water-deficit stress are genotype-dependent. Crop and Pasture Science, 66, 1024-1038. https:// doi.org/10.1071/CP15013

Manivannan, N. (2014). TNAUSTAT- Statistical package: https://sites.google.com/site/tnaustat.

Mansouri, A., Oudjehih, B., Benbelkacem, A. Fellahi, Z. E. A., Bouzerzour, H. (2018). Variation and relationships among agronomic traits in durum wheat [Triticum turgidum (L.) Thell. ssp. turgidum conv. durum (Desf.) Mackey] under south Mediterranean growth conditions: Stepwise and path analyses. International Journal of Agronomy, 1-11. https:// doi.org/10.1155/2018/8191749

Mather, K., \& Jinks, J. L. (1982). Biometrical Genetics. The Study of Continuous Variation. Third edition. Chapman and Hall, London - New York, pp. 279. https://doi.org/10.1007/9781-4899-3406-2

Mohsin, T., Khan, N., Naqvi, F. N. (2009). Heritability, phenotypic correlation and path coefficient studies for some agronomic characters in synthetic elite lines of wheat, Journal of Food, Agriculture and Environment, 7, 278-282.

Munir, M., Chowdhry, M. A., Ahsan, M. (2007). Generation mean studies in bread wheat. Internaional Journal of $\mathrm{Ag}$ riculure and Biology, 9, 282-286.

Novoselović, D., Barić, M., Drenzer, G., Gunjača, J., Lalić, A. (2004). Quantitative inheritance of some wheat plant traits. Genetics and Molecular Biology, 27, 92-98. https://doi. org/10.1590/S1415-47572004000100015

Ojaghi, J., \& Akhundova, E. (2010). Genetic analysis for yield and its components in doubled haploid wheat. African Journal of Agricultural Research, 5, 306-315.

Punia, S. S., Baldev, R. Koli, N. R. Ranwah, B. R. Rokadia, P., Maloo, S. R. (2011). Genetic architecture of quantitative traits in field pea. Journal of Food Legumes, 24, 299-303.

Rabti, A., Mekaoussi, R., Fellahi, Z. E. A., Hannachi, A., Ben- 
belkacem, A., Benmahammed, A., Bouzerzour, H. 2020. Characterization of old and recent durum wheat [Triticum turgidum (L.) Tell. convar. durum (Desf.) Mackey] varieties assessed under south Mediterranean conditions. Egyptian Journal of Agronomy, 42, 307-320. https://doi.org/10.21608/ agro.2020.43329.1230

Rad, M. R. N., Kadir, M. A., Yusop, M. R., Jaafar, H. Z., Danaee, M. (2013). Gene action for physiological parameters and use of relative water content (RWC) for selection of tolerant and high yield genotypes in F2 population of wheat. Austoralian Journal of Crop Science, 7, 407-413.

Royo, C., Nazco, R., Villegas, D. (2014). The climate of the zone of origin of Mediterranean durum wheat (Triticum durum Desf.) landraces affects their agronomic performance. Genetic Resources and Crop Evolution, 61, 1345-1358. https:// doi.org/10.1007/s10722-014-0116-3

Saleem, M., Aslam, M., Muhammad, C., Kashif, K., Khaliq. M. (2005). Inheritance pattern of plant height, grain yield and some leaf characteristics of spring wheat. International Journal of Agriculture and Biology, 7, 1019-1025

Salmi, M., Benmahammed, A., Benderradji, L., Fellahi, Z. E. A., Bouzerzour, H., Oulmi, A., Benbelkacem. A. 2019. Generation means analysis of physiological and agronomical targeted traits in durum wheat (Triticum durum Desf.) cross. Revista Facultad Nacional de Agronomía Medellín, 72, 89718981. https://doi.org/10.15446/rfnam.v72n3.77410

Shabbir, G., Kiran, T., Akram, Z., Ijaz, M., Shah. K. N. (2012). Genetics of some biometric traits in bread wheat (Triticum aestivum L.). Journal of Agricultural Research, 50, 457-468.

Shayan, S., Moghaddam Vahed, M., Norouzi, M., Mohammadi, A., Tourchi, M., Molaei. B. (2018). Inheritance of agronomical and physiological traits in the progeny of Moghan 3 and Arg bread wheat varieties cross. Plant Genetic Research, 4, 43-60. https://doi.org/10.29252/pgr.4.2.43
Singh, R. P., Huerta-Espino, J., Rajaram, S., Crossa, J. (2001). Grain yield and other traits of tall and dwarf isolines of modern bread and durum wheats. Euphytica, 119, 241-244. https://doi.org/10.1023/A:1017541805454

Sirohi, A., \& Gupta, V. P. (1993). Additive, dominance and epistatic components of variation for seed protein content in pea (Pisum sativum L.). Indian Journal of Genetics, 53, 252256.

Slafer, G. A., Araus, J. L. Royo, C., Del Moral, L. F. G. (2005). Promising eco-physiological traits for genetic improvement of cereal yields in Mediterranean environments. Annals of Applied Biology, 146, 61-70. https://doi.org/10.1111/j.17447348.2005.04048.x

Spagnoletti-Zeuli, P. L., \& Qualset, C. O. (1990). Flag leaf variation and the analysis of diversity in durum wheat. Plant Breeding, 105, 189-202. https://doi. org/10.1111/j.1439-0523.1990.tb01196.x

Steel, R. G. D., \& Torrie, J. H. (1960). Principles and procedures of statistics, McGraw-Hill Books, New York. 481 p.

Velu, G., Singh, R. P. Huerta, J., Guzman C. (2017). Genetic impact of Rht dwarfing genes on grain micronutrients concentration in wheat. Field Crops Research, 21, 373-377. https://doi.org/10.1016/j.fcr.2017.09.030

Yang, D., Liu, Y., Cheng, H., Chang, L., Chen, J., Chai, S., Li, M. (2016). Genetic dissection of flag leaf morphology in wheat (Triticum aestivum L.) under diverse water regimes. BMC Genetics, 17, 1-15. https://doi.org/10.1186/s12863016-0399-9

Yani, S. C., \& Rashidi, V. (2012). Selection indices in the improvement of wheat grain yield on drought stress conditions, the success of selection in the cross populations depend on the knowledge of inheritance pattern of the desired traits. African Journal of Agricultural Research, 7, 1177-1183. https://doi.org/10.5897/AJAR11.1616 